Published as 'Eugen Ehrlich, Living Law, and Plural Legalities', in Theoretical Inquiries in Law : 9.2 2008, (leading on- line journal )-article 6

6,http://www.bepress.com/til/default/vol9/iss2/art6 978-1841135960

\begin{abstract}
This paper examines the different meanings of Ehrlich's idea of living law in relation to current debates about legal pluralism. It distinguishes three aspects of Ehrlich's concept as these have been elaborated in the later literature: 'law beyond the law', 'law without the state', and 'order without law'. This retrospective shows that Ehrlich was not principally concerned with defending the rights of ethnic or autonomous communities as such. In taking his work further it is important to recognise how far official and unofficial law are even more interdependent than in his day. But we may still find his work of relevance for thinking about the normative challenges of plural legalities.
\end{abstract}

\title{
Eugen Ehrlich, Living Law, and Plural Legalities ${ }^{1}$
}

David Nelken

The theme of this special issue is the need to recognise the overlap between three current socio- legal developments: legal pluralism- or the

\footnotetext{
${ }^{1}$ This paper develops out of a much longer study of the influence of Eugen Ehrlich on later writers which will be published in MARC HERTOGH ed., REDISCOVERING EHRLICH, Hart, Oxford (forthcoming).
} 
granting of recognition to different forms and forums of disputeresolution, the privatisation of law - or the move towards the decentralisation of law making, and multiculturalism- the delegation of authority to sub - state communities. It is suggested that 'the thinking taking place in each of the three spheres calls for close ties to the work conducted in the other two'. The work of Eugen Ehrlich, the founder of the sociology of law, might be thought to be particularly relevant to these interconnecting themes. His apparent down-grading of the role of the Austro- Hapsburg state when it came to daily life in Bukowina offers an illustration of what might be thought to be a type of privatisation of law. $\mathrm{He}$ is widely seen as one of the first writers to point clearly to the coexistence of plural legalities. And the de facto multiculturalisim of this frontier province in which Armenians, Germans, Rumanians, Russians, Ruthenians, Slovaks, Hungarians, Jews and Gypsies lived side by side may still have something to teach us at a time in which nation-states are being reshaped in the current round of transnational population movements.

Although Ehrlich is referred to by some of the other contributors to this special issue he tends to figure only as a progenitor, a footnote from the past. The question I want to adress however is how far Ehrlich's work can still be useful today. The challenges we need to meet now would seem to be very different from those he faced before the first world war in the far flung Bukowina province of the old Austro- Habsburg empire. If Ehrlich's work is taken as an early approach to the issue of multiculturalism and law it is also one that is thought to needs updating so as to allow us to understand the legal fragmentation caused by current developments at a 
time of globalisation. One way to do this is to read him through the lens of more recent social theory such as that represented by Niklas Luhman ${ }^{2}$. Recently for example, Gunther Teubner has used Ehrlich's ideas as a foil against which to contrast past and modern legal pluralism. ${ }^{3}$ Law, he tell us is 'not drawing its strength now from ethnic communities as the old living law was supposed to do'.. ' Ehrlich', Teubner explains, 'was of course romanticizing the law -creating role of customs, habits and practices in small scale rural communities'. The global world, by contrast, he argues, relies on 'cold technical processes not on warm communal bonds'.

${ }^{2}$ See Kurt A. Ziegert, (2001) Introduction, to Eugen Ehrlich's, THE FUNDAMENTAL PRINCIPLES OF SOCIOLOGY OF LAW, Transaction Publishers, New Brunswick,: 19-44.

${ }^{3}$ Gunther Teubner, Global Bukowina: Legal Pluralism in the world society, in GUNTHER TEUBNER ed. GLOBAL LAW WITHOUT A STATE, Dartmouth, Aldershot: 3-28. (1997.

${ }^{4}$ The formulation of this sentence is somewhat ambiguous and it is therefore not entirely clear whether Teubner himself totally endorses this account of Ehrlich's ideas. Does 'supposed to do ' here mean 'as commonly thought'? But then, if Teubner knows better- why does he makes it seem as if this does represent Ehrlich's views? Or does ' supposed to do ' mean what living law 'should' reflect the different laws of ethnic communities? This would be a different claim having less to do with where law comes from than with the need to recognize cultural diversity. 
But the assumption that Ehrlich was putting forward a strong thesis of legal pluralism rooted in ethnic communities is a tendentious interpretation which has poor support in the text itself ${ }^{5}$ - even if Teubner is certainly not the only commentator to take such a line. This way of reading Ehrlich also displays the genetic fallacy by confusing factors that may have helped give rise to his argument, with the substance and validity of his ideas themselves. In fact, Ehrlich's claims were intended to be potentially universalisable ones, applicable also to settings quite different from Bukowina, and had less to do with the rights of ethnic groups than with the way law- like norms are created through everyday life in 'associations', whether we are talking about peasants' farmholdings or the behaviour of banks and other commercial enterprises in deciding whether or not to sue their debtors. This helps explain why the question of ethnic pluralism was not the main issue for early critics of Ehrlich such as Kelsen, whose objection was more to Ehrlich linking law to the actual normative practices of groups even when these were inconsistent with the Austrian legal code. ${ }^{6}$

\section{${ }^{5}$ EUGEN EHRLICH, FUNDAMENTAL PRINCIPLES OF THE} SOCIOLOGY OF LAW, (W.L. Moll, trans.) with introduction by Roscoe Pound. New York: Russell and Russell. (1936/1962).

${ }^{6}$ What is more, interpreting Ehrlich in terms of Luhmann's categories requires more than a little rewriting of what he actually said. A detailed critique of Teubner's appropriation of Ehrlich will be found in David Nelken, An e -mail from Global Bukowina, INTERNATIONAL JOURNAL OF LAW IN CONTEXT, (2007). 
A key term which Ehrlich used was that of 'living law'. As we shall see, this idea continues to be an essential point of reference for those seeking to understand phenomena such as the new lex mercatoria, the law of the internet, and the globalising spread of human rights law. So what did Ehrlich mean by living law? In what follows I shall first set out Ehrlich's definition of this key term and then go on explore three ways in which his idea has been developed in later writing. I shall argue that though Ehrlich can be and has been used to support one or other position in debates over such controversial subjects as whether the law of non - state groups should count as 'law', his aim was to help us grasp how normative patterns emerge from social life, whether or not they are then endorsed by states, legislatures, courts or administrators. As compared to when he developed his ideas, however, research shows that there is now a considerable interdependence between official and living law not only in the domestic but even in the international sphere. This will need to be borne in mind in making claims based on the possible or ideal autonomy of non- state or sub -state legal regimes. In the final section I shall draw out some of the implications of this argument for the questions raised in this special issue.

Three aspects of living law

The canonical definition of what is meant by 'living law' is usually taken to be Ehrlich's statement that, 'The living law is the law which dominates life itself even though it has not been posited in legal propositions. The source of our knowledge of this law is, first, the modern legal document; secondly, direct observation of life, of commerce, of customs and usages 
and of all associations, not only those that the law has recognised but also of those that it has overlooked and passed by, indeed even of those that it has disapproved' ${ }^{7}$ But this definition has some remarkable features. In the first place it is in large part mainly an indication of method. It tells us where to look (and how to look) for something, but the existence of that something is predicated on unspecified theoretical grounds. It is also difficult to see what his examples have in common other than the fact that they may all be illustrations of normative phenomena that elite lawyers in Vienna may not know about - or even want to know about. In any case, as is usual in the development of academic disciplines, what is presented by Ehrlich as one theoretical category is seen by later writers as grouping together a number of not necessarily homogenous phenomena. Following up the later reception of Ehrlich's work in the relevant secondary literature we will find that we have to deal with different legacies rather than assume that scholars have all taken the same message from what he wrote.

In his description of living law, Ehrlich puts together the creation or employment of law by lawyers (and others), the rules and usages of associations that are 'recognised' by or will develop into (state) law, as well as, most remarkably, the shared practices of associations that are disapproved of by the state and have no aspiration to be included in the sway of its law. Some later scholars who follow him have mainly shown interest in what else law does - the actual practice of legal officials, administrators as well as all those who use or are affected by the law.

${ }^{7}$ EUGEN EHRLICH, supra at 493. 
Others have focused more on what else does law, even to the extent of detecting the existence of rival legal systems. Finally, yet others are searching for the sources of normative order, what Durkheim called 'the pre- contractual basis of contract' . ${ }^{8}$ For the purposes of illustration it may be helpful to distinguish developments in the study of law beyond the law, (law other than that contained in statutes and judgements), law without the State, (especially the coexistence of plural legal regimes), and order without law (the implicit norms that make order possible).

There is certainly some overlap between the phenomena that are studied under each of these rubrics, and this goes beyond the common denominator that we cannot afford to restrict ourselves to the study of legal codes and court decisions if we want to understand' law in society'. But there are also important differences in the issues that each of them raise. If we may wonder whether Ehrlich was right to combine into one category his examples of youngsters giving over the pay for their work to their parents, and businessmen not insisting on being paid by their creditors, the situation becomes even more complex when we seek to include as examples of living law the avoidance of legal relations by automobile dealers, the alternative sanctioning mechanisms used by diamond merchants, or the accepted practices of queuing for the cinema. Because the differences may be as important as what they have in common we shall deal with each of these aspects separately.

\section{${ }^{8}$ EMILE DURKHEIM, THE DIVISION OF LABOUR IN SOCIETY,} Free Press, New York, (1964) 
The law beyond the Law

The first part of Ehrlich's definition reminds us, as he would put it, that Law 'cannot imprisoned in a code'. We need to go 'beyond' the law books so as to take into account both the role of society in generating state law and judicial sentences and the way it shape laws and decisions as they seek to influence social life. Ehrlich's exemplar, the 'modern legal document' might not at first sight seem as the most obvious starting point for grasping this aspect of living law. But those who engage in the sociology of substantive areas of law certainly can learn a great deal from focussing on legal documents. Many of the books in the path- breaking 'law in context' series (published in the UK from the 1960's onwards) did exactly this, gathering information about the contracts used by consulting engineers, or the standard form contracts of hire purchase or dry cleaners, so as to reveal a world of law at variance with that presupposed by the more traditional textbooks. Giving attention to documents is also crucial to understanding the construction of transnational legal agreements and regulatory modes by legal professionals.

It is impossible to trace the full influence of Ehrlich's insights here - these are now woven into the warp and woof of sociology of law. Ehrlich's claim that 'the centre of gravity of legal development lies not in legislation, nor in juristic science, nor in judicial decision, but in society itself' could well be taken as the leitmotiv of the contributions to the field by Lawrence Friedman, one of the most distinguished of contemporary 
social historians of law. More generally, the argument that there is more to law than what can be found in statutes and court decisions is constitutive of any interdisciplinary approach to law. All the most famous studies over the last 50 years (mainly, it has to be said, coming from the United States), such as those by Macaulay or Galanter, have mainly to do with the way non- legal factors shape the use of law. At first sight it might be thought that 'law in action' is not strictly relevant to this confenrece Non state law but often related expression of living law ceratinly is is state law result of orgamnisations develop own loyalties nothing to do with state . Moreover any attempt to delegate or divide up normative orders will need to bear in mind this distinction.

But the idea that there is a law beyond the law has not always been taken in the same direction. Many have followed Pound and the Legal Realists in studying the 'Law in action' so as to explore the practical implementation of laws or of judicial and administrative decisions ${ }^{9}$. Others have sought rather to understand the 'legal consciousness' of those who use or are affected by the law, showing how ideas of legality and what it represents circulate and shape such consciousness at least as much as they are its product. ${ }^{10}$ Marc Hertogh has sought to integrate Pound's common law and

${ }^{9}$ The alleged equation between 'law in action' and 'living law' is examined critically in David Nelken, Law in Action or Living Law? Back to the Beginning in Sociology of Law, 4 LEGAL STUDIES: 157. (1984). ${ }^{10}$ SUSAN SILBEY and PATRICIA EWICK, THE COMMON PLACE OF LAW, University of Chicago Press, Chicago, 1998; Susan Silbey, 
Ehrlich more continental approach in order to investigate the interaction between law in action and legal consciousness. His case study of the use of discretion by housing officials shows how they mediate between the legal principle of formal equality enshrined in the Rechtsstaat and a wider popular legal consciousness which values responsiveness and material equality. ${ }^{11}$

At the same time the claim that law has more to do with its given local context than with the wider process of rule production in the legislature and courts has never been uncontroversial. As Rheinstein pointed out in an early appraisal of Ehrlich's work ${ }^{12}$, this is likely to vary by types of law. Later empirical research showed that forms of law, such as that to do with labour relations, did not necessarily correspond to particular forms of social organisation in ways that would be expected ${ }^{13}$. There have also been

After Legal Consciousness, 5 Annual Review of Law and Social Science: 323-368. (2005)

${ }^{11}$ Marc Hertogh, A 'European' Conception of Legal Consciousness: Rediscovering Eugen Ehrlich, 31 JOURNAL OF LAW AND SOCIETY: 457- 481 (2004).

${ }^{12}$ Max Rheinstein, Sociology of law, Apropos Moll's translation of Eugen Ehrlich's Grundlegung der soziologie des Rechts, JOURNAL OF ETHICS, 48: 232-239. (1938).

${ }^{13}$ STUART HENRY, PRIVATE JUSTICE: TOWARD INTEGRATED THEORIZING IN THE SOCIOLOGY OF LAW, Routledge and Kegan Paul, London, (1983) ; David Nelken, 'Beyond the Study of "Law and 
some attempts to break out of the whole paradigm of trying to fit 'law' to 'society'.${ }^{14}$ Most radically, Luhmann, first in his systems theory approach, and even more in his autopoietic social theory, insisted that law could only relate to its own communicative constructions of its environment rather than actually have direct connections with it.

Legal historians and comparative lawyers have often stressed that law can be out of step with society, or be linked to foreign sources rather than being embedded in the society in which it is found ${ }^{15}$. The obvious response is that the law that 'really' matters will always be that which is actually operating and therefore being shaped locally. But this risks being tautological. For others, both critical legal scholars and some post-modern social theorists, on the other hand, law is even more tightly bound up with society than Ehrlich thought. It is state law, official law, that shapes

Society",' (1986) American Bar Foundation Research Journal, 11. 2 : 323338; Gary Itskowitz, Social Theory and Law: The Significance of Stuart Henry, (1988) 22 Law \& Society Review: 949-962.

${ }^{14}$ David Nelken, (1986) op.cit and David Nelken, Changing Paradigms in the Sociology of Law, in Gunther Teubner (ed.) AUTOPOIETIC LAW: A NEW APPROACH TO LAW AND SOCIETY, De Gruyter, Berlin,): 191217. (1987).

15 David Nelken, Comparativists and Transferability, in PIERRE LEGRAND and RODERICK MUNDAY eds. COMPARATIVE LEGAL STUDIES: TRADITIONS AND TRANSITIONS, Cambridge University Press, Cambridge: 437-466. (2003). 
society's deepest conceptions quite as much as the reverse. Some speak here of Law's constitutive role. In a recent discussion of intellectual property law, for example Rosemary Coombe and Jonathan Cohen argue that 'a critical cultural legal studies reveals that law is fully imbricated in shaping lifeworld activities, bestowing propriety powers, creating markets, establishing forms of cultural authority, constraining speech, and policing the public/ private distinction (that protects corporate authors from social accountability. ${ }^{16}$ As they go on to say, 'Law is a palpable presence when people create their own alternative standards and sanctions governing the use of corporate properties in the moral economies that emerge in law's shadows'. Intellectual property law does not function in a rule like fashion as a regime of rights and obligations but also simultaneously as 'a generative condition and prohibitive boundary for practices of political expression, public- sphere formation, and counter- public articulations of political aspiration, 17 .

For Ehrlich the key to the unfolding of law was to be found in the role of associations. Amongst the many important developments of this idea may be noted Karl Renner's demonstration - this time as seen from Vienna, rather than from the periphery- that codified property law could easily

\footnotetext{
${ }^{16}$ Rosemary Coombe, with Jonathan Cohen, The law and late modern culture: Reflections on 'between facts and norms' from the perspective of critical legal studies, 76 DENVER UNIVERSITY LAW REVIEW: 1029 at 1031. (1999).

${ }^{17}$ Coombe and Cohen, op.cit: 1043.
} 
become no more than a dead husk in respect of the actual developments in the actual organisation of capitalist firms or large rented tenements ${ }^{18}$ From the 1950's on the work of Lon Fuller at Harvard and Philip Selznick at Berkeley examined roots of (and the need for) 'legality' within the structure of organisational life. ${ }^{19}$ The most recent studies by Lauren Edelman and her collaborators, also based in Berkeley, using the approach of institutional sociology to focus on the role of organisations, confirm Ehrlich's ideas about the role of associations in creating the living law. On the other hand, they also show that official norms and those of the organisations themselves are (now) far more intertwined and interdependent than Ehrlich envisaged when first contrasting living law and 'norms for decision'.

In one recent paper which deals with organizationally constructed symbols of compliance following the 1964 Civil Rights Act ${ }^{20}$ Edelman et.al. coin

${ }^{18}$ KARL RENNER, THE INSTITUTIONS OF PRIVATE LAW AND THEIR SOCIAL FUNCTION, Routledge and Kegan Paul, London, (1949).

${ }^{19}$ LON FULLER, . AND KENNETH WINSTON, THE PRINCIPLES OF SOCIAL ORDER, Hart, Oxford, 2001; PHILIP SELZNICK, LAW, SOCIETY AND INDUSTRIAL JUSTICE, Russel Sage, New York, (1968).

${ }^{20}$ Lauren B., Edelman, Linda Hamilton Krieger, Scott R Eliason,., Catherine Albiston, and Virginia A Mellema, When Organizations Rule: Judicial Deference to Institutionalized Employment Structures (June 21, 
the term ' legal endogeneity'. This refers, they say, to ' a subtle and powerful process through which institutionalized organizational practices and structures influence judicial conceptions of legality and compliance.' They argue that 'organizational structures such as grievance procedures, anti-harassment policies, evaluation procedures, and formal hiring procedures become symbolic indicia of compliance with civil rights law...as they become increasingly institutionalized, judges begin to use their presence or absence in evaluating whether or not an organization discriminated. Ultimately, these structures becomes so closely associated with rationality and fairness that judges become less likely to scrutinize whether they in fact operate in a manner that promotes non-discriminatory treatment.' As Rheinstein suggested, however, we should be careful before generalising too much from intellectual property law or antidiscrimination law. As Edelman et. al themselves note, lawmaking that sets forth broad and often ambiguous principles give organizations particularly wide latitude to construct the meaning of compliance.

\section{$\underline{\text { Law without the state }}$}

The second approach to living law that we can trace back to Ehrlich is one less focused on how official law is shaped or reshaped and more interested in uncovering the existence of legal regimes that do not have or need the backing of the state. The key problem here, which is also central to this

2006). 1st Annual Conference on Empirical Legal Studies Paper . Available at SSRN: http://ssrn.com/abstract=910940 
special issue, is how to take into account the fact that there can (also) be non -state law, and sub- state private legal regimes. As Teubner puts it, for this literature, 'law or not law is the question'. Although Gurvitch has stronger claims than Ehrlich to having developed a rich (even over rich) sociological theory of plural legal orders ${ }^{21}$ discussions about legal pluralism often refer to Ehrlich's writings and current debates continue to make explicit reference to his ideas. Unfortunately, however, many writers still tend to reduce Ehrlich's contribution to the importance he allegedly attributed to preserving ethnic and cultural pluralism. But the varied examples of living law he offered, which included businessmen not insisting on claiming their debts, give the lie to such reductivism.

Ehrlich famously argued that the state does not have a monopoly over the law. He would also have agreed with Llewellyn (who in fact was an admirer of his work) when the latter argued later that ' law jobs' do not have to be done by state institutions. Although Ehrlich focused mainly on the jurisgenerative propensities of communities and associations his writing has also rightly been taken as inspiration for those have gone on to argue, more broadly, that more or less autonomous 'social fields' can create their own set of norms and sanctioning mechanisms ${ }^{22}$. The focus of more

${ }^{21}$ GEORGES GURVITCH, SOCIOLOGY OF LAW, Routledge Kegan Paul, London, (1947).

${ }^{22}$ Sally Falk Moore, The Autonomous Social Field as an Appropriate Subject of Study, 7 LAW \& SOCIETY REVIEW: 719-46 (1973); Lisa Bernstein, Opting Out of the Legal System: Extralegal Contractual 
recent writing, however, is on the way that globalisation is increasingly 'uncoupling' law from the state. Transnational enterprises and transnational forms of communication and regulation have thus emerged as an important new source of legal pluralism.

Two key examples of such new forms of legal pluralism which have provided the occasion for rediscovering Ehrlich's ideas about living law are lex mercatoria, as discussed for example in Teubner's collection Global Law without a State ${ }^{23}$, and the governance of the internet, as in Rowland's discussion of 'Law in Cyberspace' . ${ }^{24}$ For these authors, as for many other commentators, the question of whether these regimes can be described as law is strongly linked to the issue of whether they should be so recognised (as if 'calling' them law will help make them so). And the answer is not necessarily the same in each case. whilst the first has to do more with norm making by or for businessmen as an attempt to create interstitial order, the other has to do with an allegedly virtual space.

Relations in the Diamond Industry, 21 JOURNAL OF LEGAL STUDIES: 115. (1992).

${ }^{23}$ Gunther Teubner, op.cit. (1997).

${ }^{24}$ Rowland, D. Cyberspace - A Contemporary Utopia?, 3 THE JOURNAL OF INFORMATION, LAW AND TECHNOLOGY, (1998) http://elj.warwick.ac.uk/jilt/98-3/rowland.html>. New citation as at 1/1/04: http://www2.warwick.ac.uk/fac/soc/law/elj/jilt/1998 3/rowland/ 
In an important article which he examines both phenomena from the point of view of an expert on conflicts of law, Ralf Michaels compares them in relation to the different criteria that can be used for defining law. He accepts that both lex mercatoria and the internet can promote social ordering and social control. But, he claims that whilst the new law merchant also aims at dispute resolution this is less clear with the internet. Moving to the structural criterion, law merchant imposes binding obligations on tradesmen, while the internet, he rightly suggests, controls rather through its technology, its architecture. Law merchant is referred to by some (though not all) participants as law; this again, is true for the internet. Certainly, merchants consider themselves some kind of "community", the same may be true of users of the internet. He concludes that while the new law merchant has a good claim to qualify as "law" under most named criteria, proponents of an autonomous internet law have a harder case to make. ${ }^{25}$

Nonetheless, Michaels insists that, from a juristic perspective, neither of these regimes, nor any other legal system which can be shown to be only semi- autonomous, can be rightly described as law. The crucial point for him is that they all require the state to 'recognise' their legal validity. He points out that we do not let parties develop any private law they choose. If , for example, the diamond merchants studied by Bernstein 'wanted to cut

${ }^{25}$ Ralf Michaels, The Re-Statement of Non-State Law: The State, Choice of Law, and the Challenge from Global Legal Pluralism, 51 WAYNE. L.REV.:1209. at 95 ff. (2005) 
off the hands of dealers who broke their contracts, the state would interfere - just as it does with the private law systems of organized crime. ${ }^{, 26} \mathrm{In}$ practice, Michaels explains, the state has three ways to cope with other normative orders: incorporation, delegation, and deference. Through incorporation, which applies for example to lex mercatoria, rules count as law only insofar as they become part of the law of the state. This, he argues, ' is perfectly compatible with Ehrlich's insight that the production of law mainly happens on the periphery, within society. Yet the insight loses its revolutionary potential. The state is able to domesticate this potentially subversive development through the incorporation of the norms that are created. It recognizes non-state communities as generators of norms, but it denies these norms the status of autonomous law. Instead, by incorporating these norms into state law, the state reiterates its own monopoly on the production of legal norms'.

Michaels also refers to Ehrlich's arguments when discussing the strategy of deference. ' (T)he state', he explains,' may leave it to commercial practices and professional standards to develop the appropriate standard of care, the typical expectations necessary for interpreting contracts, etc. This is the approach most frequently seen as an answer to Ehrlich's "living law". Again, living law is not ignored by the law of the state, but neither is it recognized as law. The state and its law do not conceptualize their relation

\footnotetext{
${ }^{26}$ The fact that Ehrlich actually included this as an example of what he called living law suggests that he was not looking for a criterion of legal validity.
} 
to such spaces of private ordering as a relation to foreign laws, to be handled by rules of conflict of laws. Rather, the state refrains from interfering, or, put differently, it defers to the private interactions of individuals. The whole public / private distinction, as we know well by know, takes place within the framework of the state's law. Private ordering enters the substantive law of the state at the time of enforcement as fact as customs, general expectations, etc., that must be taken into account in the application of the state's laws, but that do not constitute such norms in themselves.

Finally, Michaels tells us, ' A third operation, somewhat similar to deference, treats such orders as legal orders separate from the state's own law, but still denies them full autonomy. This process can be called delegation. Instead of regulating on its own, the state defers to the selfregulation by interested groups. Examples of delegation abound. Autonomous labour agreements between unions and employers have the force of law; codes of conduct of regulated or unregulated industries substitute possible regulation by the state, etc. Indeed, this idea of the contract was one basis for the idea of the new law merchant ("contrat sans loi"). in the very moment in which they are attached and subordinated to the state and its law... Non-state law turns into sub-state law.

Michaels is very wary of crediting 'communities and fields with the power to create law. But he admits that his juristic perspective, one ' intrinsic to operations of the legal system itself' is not the only way to look at the question. ' (L)egal pluralism, legal sociology and legal anthropology' he 
explains, ' may well have different definitions of law, because they are interested in different aspects of law. And, for their part, even those sociologists and anthropologists most committed to the idea of legal pluralism will concede that the state will usually seek to deny the legitimacy of rival regimes. Michaels is quite willing to admit that, from a sociological or anthropological perspective, it may (or may not) make sense to refer to all normative orders in communities as "law". In fact, both legal scholars and social scientists are be found on both sides of the divide regarding whether we should describe rival or sub state legal regimes as law.

Legal scholars such as Berman (with whom Michaels polemicises) argue that communities have the power of ' jurispersuasion'. ${ }^{27}$ In a provocative recent essay, Melissaris even extends the notion of communities to groups such as queues arguing that ' Only when the legal commitment of clubbers who queue patiently at a bouncer's orders is treated as seriously as the legal commitment of communities with religious or other moral bonds will the pluralistic study of the law be able to move away from the essentially positivistic external study of groups to the study of legal discourses.' ${ }^{28}$ But some would say this was a reductu ad absurdum. Anthropologists have

${ }^{27}$ Paul. S. Berman, From International Law to Law and Globalization, 43 COLUM J. TRANSNAT'L L. 485. (2005).

${ }^{28}$ Melassaris, E. The more the merrier? A new take on Legal Pluralism, 13 SOCIAL AND LEGAL STUDIES: 57-79 at 75. (2004). See also Reisman's book discussed in the next section. 
been amongst those most convinced that state law is far too narrow a perspective for many of the societies they study ${ }^{29}$. But other social theorists, such as Brian Tamanaha, argue that what is crucial is the way people use the term 'law' - which usually privileges state law. ${ }^{30}$ It has even been argued that extending the label 'law' to non state regimes means imposing a state- like definition of law. For Simon Roberts, "Law, long so garrulous about itself, is now, in its contemporary enlargement, graciously embracing others in its discourse, seeking to tell those others what they are. $^{31}$

But, whether or not social scientists are entitled to use the term law as they wish, a more important question has to do with how far Ehrlich's notion of living law helps or hinders our understanding of these emergent phenomena. Take, for example, law- making by cyber communities. In a relatively early paper on this topic, which explicitly takes its inspiration from Ehrlich, Rowland makes an effort to tease out the living law of such communities. She argues that the "impact of new communications

${ }^{29}$ For a strong statement see Franz von Benda-Beckmann, Comment on Merry, LAW \& SOCIETY REVIEW, 22, 5. 897-902. (1988)

${ }^{30}$ Brian, Z. Tamanaha, The Folly of the "Social Scientific" Concept of Legal Pluralism, 20 JOURNAL OF LAW \& SOCIETY: 192 (1993); Brian, Z. Tamanaha, A Non-Essentialist Version of Legal Pluralism, 27: JOURNAL OF LAW AND SOCIETY: 296. (2000)

${ }^{31}$ Simon Roberts, Against Legal Pluralism, 42 JOURNAL OF LEGAL PLURALISM: 95-106. (1998). 
technology on both social relationships and law-making processes is still in its infancy.. that $(\mathrm{t})$ here are myriad political processes at work in all societies but the decentralized nature of the Internet makes it particularly difficult to understand either the manner in which power can be exercised, by whom and within what limits'. For her, we need to face the fact that cyber communities 'challenge state- based models of lawmaking as well as many of our preconceptions of the attributes of society and community, 32 .

Rowland expresses concern about 'imposing on the organization and use of the Internet a social construct which is entirely inappropriate both in idea and substance'. 'Thus far,' she argues' legal rules external to Cyberspace have not been conspicuously successful at regulating the global computer network..( and) ... may only succeed in regulating Cyberspace when the social conditions pertaining in cyber communities are acknowledged and understood'. One can imagine Ehrlich sharing such cautions. At the same. however, she suggests, law may be forming itself ' from below'. Legal rules, she tells us, ' may already be emerging from amidst the chaos of Cyberspace...in some respects the cyber community, at this juncture, could be regarded as a 'pre-legal' world and the change to a legal world will inevitably involve the creation of rules dealing with change, adjudication and recognition of rights. Most communities will regulate themselves, in practice, by a combination of formal or 'book law' ('top-down' rule formation) and also by acknowledgement of the

${ }^{32}$ ROWLAND, 1998 op.cit 
customary rules which have evolved to supplement this source of law and to cater for what 'actually happens' ('bottom-up' regulation). Examples are the rites of passage, initiation or induction for newcomers to that community which either enable them to integrate more easily, or, conversely, create a barrier to entry to the society which must be successfully negotiated.

For Rowland, progress towards a self regulating internet law is at best uneven. Although certain customs in cyber communities 'appear to be in the process of being elevated to the status of customary rules... many rules remain purely customary, having no enforceable sanction attached to their non-adherence, indeed it is doubtful whether a universally enforceable sanction can be applied in Cyberspace.' Rowland concedes that we do not have' to measure the success of custom as a regulatory mechanism purely by the availability of express sanctions. Successful customs may be obeyed, not so much because of the threat of sanctions, but for fear of standing out from the crowd. Such rules may be adhered to not out of personal conviction, but, rather, as an indication that such conduct is conventionally accepted and so participants are happy to accept it as a standard of assessment. People may also accept rules not necessarily because of any issue of morality but possible out of fear, self-interest, coercion or habit'. Nonetheless, 'what is not apparent in cyber communities is such an assurance of acceptable behaviour, at least as judged by the prevailing standards and mores of the physical world. In comparison, the range of norms and values in cyber communities seems to cover a much wider and more diverse range. What may be absent in the 
virtual world is the necessary degree of uniformity and unanimity defining a custom which has the capacity to metamorphose into a legal rule and become both binding and obligatory.'

The literature on internet law has grown exponentially since Rowland posted her reflections (though it does not as far as I am aware make much reference to Ehrlich). The question of what norms are appropriate for cyberspace (and providing them with a history or legitimacy) has changed as the internet itself has developed from an idealised utopia of caring and sharing- with its folkloristic evolution of norms of good manners- to an ever expanding site for commercial activities as well as the exploitation of the less attractive aspects of human sociability. It is less and less possible to think of users mainly in terms of on -line communities- and some of the communities that do exist in this space use the internet to spread hate propaganda aimed at others ${ }^{33}$. But it continues to surprise. Pressed into service by the market it can sometimes rise up against property rights as where users collectively reveal trade secrets. Seemingly feeble in the face of the armed might of the state, the diffusion of video photographs provides the evidence to protest at the conduct of military operatives and secret police from that in United States military installations to police stations in Egypt.

${ }^{33}$ ANTONIO ROVERSI, L'ODIO IN RETE, Il Mulino, Bologna, (2006) (being translated for Ashgate Press) 
The internet is not a world apart. It belongs to and helps further those economic developments by which consumers (those who can afford to consume) come more and more to play the role of producers. The real and virtual worlds intersect as shown through the application of copyright law or privacy protections. The problems it throws up mirror many of the crimes and civil wrongs found in the real world. What goes on in the virtual world of 'second life' is all too reminiscent of what happens in ordinary life. The internet provides occasions for blogging feuds, cyber bullying, defamatory Google bombing, misuse of ' spiders' or cookies, and the all too evident spread of spamming. Enforcement of norms is complicated by the use of anonymity and the difficulty of knowing when users can be assumed to be informed of norm changes. On the other hand, sanctions from which there is no appeal, for example where users are banishing users from given sites, may be considered too severe to be left to private parties.

Insofar as internet does maintain a sort of autonomy there is scope for more investigation into how far group exercises in rule making and rule application are constructing a distinctive form of living law. The collective encyclopaedia Wikipedia, for example, does use law- like procedures for rule making and fact finding as ways of deciding whether an article's content is sufficiently evidenced, whether links to other entries are justified, what counts as an insult, and so on. But there is a need here too for protection from the guardians. In March 2007 for example there were reports about a fake professor known as Essjay whose 'authority' to arbitrate disputes and remove site vandalism about articles on religion 
turned out to be based on false credentials: He was obliged to resign from his role because, as the co-founder explained, the encyclopaedia relies on 'trust and tolerance'.

\section{Order without law}

The third literature that can be connected to Ehrlich's ideas about living law is one less interested in how associations impose their norms and more in how patterned behaviour gives rise to the working orders of associations. Order rather than law is the focus here, as seen in such titles Robert Ellickson's celebrated Order without law - How neighbours settle disputes, ${ }^{34}$ or Eric Posner's A theory of norms ${ }^{35}$. The same is true even of Michael Reisman's Law in Brief encounters -despite having law its title ${ }^{36}$. This line of enquiry can be distinguished from the previous literatures considered so far insofar as it refuses legal centralism not by contrasting the centre and the periphery or by hypothesising the existence of rival legal regimes, but by questioning the centrality of law as compared to norms. Writers seek to explain the origin and content of norms, in

\section{${ }^{34}$ RICHARD ELLICKSON, ORDER WITHOUT LAW: HOW NEIGHBOURS SETTLE DISPUTES, Harvard University Press,} Cambridge, (1991).

${ }^{35}$ ERIC POSNER, LAW AND SOCIAL NORMS, Harvard University Press, Cambridge, (2000).

${ }^{36}$ WILLIAM M. REISMAN, LAW IN BRIEF ENCOUNTERS, Yale University Press, New Haven, (1999). 
particular they develop theories of norms in the context of cooperation, collective solutions and welfare maximisation. Even if not all writers on these topics take their cue from Ehrlich, at least some of this work can also be traced back to him. Especially relevant is his advice to move from studying conflict to understanding order, to distinguish situations 'at war' from those 'at peace', and to think about expectations as much as sanctions- or of expectations as sanctions. His controversial attempt to distinguish legal from other types of norms also shows him addressing these issues.

There is by now an enormous multi- disciplinary library - ranging across evolutionary biology, psychology, philosophy, law, economics- and sociology -which deals with the source and efficacy of norms. Sociology of law alone will not be able get to master this subject. But once Ehrlich's ideas about living law are seen to embrace a wide range of normative phenomena this leads to a richer set of questions than merely whether the norms of semi- autonomous associations count as law. We are led to investigate the relationship between law and norms. How and when do norms turn into law (as in the case of the internet or lex mercatoria)? How does law become normative? When do norms mandate not following or using law? How far norms do depend on associational life. How big or amorphous must such associations be? What about the fact that we are simultaneously members of very many associations? As this suggests, research on order without law tends to be more radical than merely looking for the law beyond the law. Take, for example, Macaulay's famous findings about the extent to which businessmen did not conduct their 
exchanges on the basis of contract law relying instead on the shared norm of 'keeping one's promises' and 'standing behind your product' which provide the underpinnings of normal business behaviour ${ }^{37}$. Those interested in norms would then want to go further and ask about the social origins of such norms and they way they are reproduced.

Whatever plausible links can be drawn between this sort of work and Ehrlich's writings, in practice it can often be difficult to assess his actual influence. This can be well illustrated by considering the reference Ellickson makes to Ehrlich in his book 'Order without law'. Ellickson's claim is that 'impersonal norms are among the most magnificent of cultural achievements'. To understand them better he sets out to synthesise insights from the sociology of law and economics and law. He criticises sociologists of law for treating the content of norms as exogenous and being too satisfied with thick descriptions rather than cumulative testable theory. He argues that we must learn what norms are, not just how they are transmitted. Law and economics writers, on the other hand, he sees as too obsessed with the relationship of norms to wealth maximisation and the problems of how groups can overcome the problem of ' free riders'. Ellickson's goal is to produce a ' general theory of social control', one that could predict, on the basis of independent variables describing society, the content of the society's rules. These would in turn need to be distinguished as substantive, remedial, procedural and controller- selecting.

${ }^{37}$ Stewart Macaulay, Non- contractual relations in Business 28 AMERICAN SOCIOLOGICAL REVIEW: 55. (1963) 
In this book, however, he settles for the more modest aim of illustrating the logic of one social sub- system, that of 'informal social control'. To develop his predictions Ellickson draws on his own empirical study of rancher's communities as well as historical research into dispute resolution in whaling communities. To explain the rationality of cooperation in the absence of law, he describes the details of dispute processing, the events which trigger sanctions, and how relevant information is gathered. What is of interest for us is that it is not until page 150 that he actually makes any reference to Ehrlich. At this point he tells us blithely that 'Ehrlich believed that law is relatively unimportant and that social forces tend to produce the same norms in all human society ${ }^{38}$. Ellickson then goes on to explain that Ehrlich (like Durkheim) is to be seen as a functionalist who saw the sanctioning of norms as the way social groups maintained their solidarity. And he complains that functionalist arguments are circular because they do not say for which groups the function is being performed and assume that organisms have a objectively determinable state of health.

Ellickson is clearly not interested in providing us with a rounded analysis of Ehrlich work. But it is still surprising to find such a superficial reading coming from such an eminent scholar. Did Ehrlich really believe 'that law is unimportant'? Ellickson just assumes that whatever Ehrlich is talking about it is not law, because he (along with many others) insists that State law is likely to be inefficacious unless backed up by other norms. But it

${ }^{38}$ ELLICKSON op.cit. p. 150 note 62. 
could as well be argued that by introducing the concept of 'living law' Ellickson exaggerates the importance of law by finding it everywhere. Certainly this is the interpretation favoured by those legal pluralists who take Ehrlich as a warrant for characterising rival normative schemes as law, to all effects. As far as the charge of functionalism is concerned, Ehrlich may indeed be interested in showing us how associations use law like norms to solve problems of functioning and reproduction, But he also offers examples of behaviour, as for example where businessmen do not insist on collecting their debts, which go beyond this role. More fundamentally, his book also contains discussions of how norms reflect changing interests which it is the judges' task to reconcile in the direction of progressive social change .

Ellickson's synthesis of economics and law and sociology of law leans towards a rational actor perspective. Most of the many other recent studies of norms tend to be even more influenced by the individualistic bias of economics of law and of game theory. A recent study by Eric Posner, for example, also links norms to the question concerning the rationality of cooperation ${ }^{39}$ Posner sees norms as rules that distinguishes desirable from undesirable behaviour and give third parties authority to punish. He is particular interested in showing how norms play a role in allowing actors to avoid dilemmas of non- cooperation by signalling their willingness to be reliable collaborators rather than act as free riders. He offers some interesting insights into how and when the following of norms can help

${ }^{39}$ POSNER op.cit. 
participants distinguish genuine from false signals. He also discusses how law tries to harness the strength of norms and when legal regulation should or should not be used instead of relying on norms.

But, for all its plausibility, the claim that order relies more on shared norms than on official legal processes has also been critiqued. Insofar as Ellickson's arguments are based on empirical research they are open to counter -examples based on other case studies. Thus some research has also shown that resort may be made to official type law even in what would appear to be ideal conditions for maintaining order without law. Eric Feldman, an expert on Japanese law, has recently offered a fascinating and finely grained account of the workings of what he calls the tuna court in the Tokyo fish market. ${ }^{40}$ Here post-auction disputes between dealers and buyers, mainly regarding hidden defects in the fish, are routinely and expeditiously resolved by judges in ways that reinforce rather than substitute for the cooperation between the participants. Feldman claims that his case- study goes against what Bernstein, Ellickson and others would predict, given that these participants form a community of continually interacting players who could be expected to create their own informal normative order. In Ehrlich's language we see here an illustration of the way norms for decision can also guarantee peaceful coexistence. What is more, this preference for court -like procedures is

${ }^{40}$ Eric Feldman, The Tuna Court: Law and norms in the world's premier fish market, 94 CALIFORNIA LAW REVIEW: 2. (2006). 
found in a culture which many (though not Feldman himself) see as one normally geared to the avoidance of law.

Ellickson's work, and, in general, the arguments of the so- called 'new norms jurisprudence', have also been subjected to more fundamental theoretical objections. As we have already noted in discussing 'the law beyond the law', it is also (increasingly) difficult to draw the line between sources of order within and outside a given setting. Even if it is not official law that produces order there is likely to be some symbiosis between its projected order and the actual order shaped by and within the association or organisation. It can be a mistake to credit the idea that norms produce order independent of models in the larger environing framework. Mitchell, for example, has recently complained that 'there is little attention paid to the way in which group norms or private law systems relate to or are influenced by either legal, moral or customary norms that permeate the society as a whole. ... norms - whether the norms of the Elks Club, the New York Diamond Merchants Exchange, various religious groups, or the automobile insurance industry, are at some level inseparable from the web of norms that influences the behaviour of each of the members of these groups. ${ }^{41}$

Mitchell proposes that we speak not of 'order without law', but 'order within law'. As he says, 'The private law systems noted by Ellickson and

${ }^{41}$ Lawrence. E. Mitchell, Understanding Norms, 49 UNIVERSITY OF TORONTO LAW REVIEW: 177-248. at 255. (1999) 
Bernstein are grounded on the notion of legal obligation and legal order that pervades our society. Or, to put the claim more modestly, the legal systems which these private law systems mimic have been so pervasive in our society for so long that it seems unlikely that the new norms theorists can separate out the influence of the legal order upon the creation of private law norms'. Mitchell's point is that official law serves as a model even when its details are not known or understood. 'The problem with Ellickson's work' he says, ' is not the valuable field study but rather the conclusions he draws. Ellickson found what he took to be a startling conclusion. When neighbours had border disputes or arguments over fences or over trespassing livestock; they didn't sue each other - they negotiated out their difficulties in a way that - given the repetitive nature of the issues - became regularized. This he viewed as the spontaneous generation of order and the irrelevance of law, supported by the fact that, when surveyed, most of his interviewees either didn't know the governing law or got it wrong.

'Ellickson's ranchers might not have known the law. They might have thought they knew the law but gotten its principles wrong. They might have made up their own rules to avoid litigation. But there is one thing that I am certain that they did know; there was law, that law governed the kinds of disputes in which they engaged, and that law was available to them should they choose to use it (as sometimes they did). In other words, Ellickson's ranchers were resolving their disputes on the broad background of an understanding of legal obligation that is immanent in our society and derives from the notion of a society governed by a system of laws- when 
one person causes damage to another's person or property, there are circumstances under which the law (if invoked by lawsuit) will hold that party to account. The idea of legal order already existed in Shasta County - what Ellickson found that was different were the principles that were applied.'

The fact that the literature about norms is so vast also means that it is riven by almost as many disagreements as is the case for arguments about the nature of law. Differences in definitions, regarding for example how far norms should be seen more as instruments or as cultural constraints on action, tend to reproduce major divisions in sociological approaches to society. Others reflect the choice between privileging a more macro or micro focus on social life. Some efforts to locate the source of normative order go beyond the level of Ehrlich's focus on associations or the interactions of people involved in repeated relationships. The international legal scholar Michael Reisman claims to have discovered what he calls the micro -law of relatively fleeting relationships. In a series of well- observed descriptions Reisman shows that people handle the problems of everyday life as if they were small -scale analogies of the larger problems of legal $\operatorname{order}^{42}$. He explains how norms enable people to have a sense of what is and is not appropriate in situations such as those of looking at others, in talking with equals, or with the boss, in making queues and holding places for others in line. Decisions about such matters cannot be and are not

\footnotetext{
${ }^{42}$ But it has been objected that the individuals Reisman discusses tend to be middle class people with middle class responses.
} 
arbitrary or else such valuable institutions as the queue would break down 43

Although he entitles his book Law in brief encounters, what Reisman actually sets out to describe is (only) a form of de facto living law. He cannot mean that the rules generated in these situations are already (official) law because he goes on to ask when law should recognise or interfere in these micro- legal orders. In general he is favour of keeping state bureaucracy out of such matters. But he (as an international lawyer?) does also suggest that there are some standards that micro- law must pass and "that the practices of all groups must be appraised in terms of the international code of human rights" so that "practices inconsistent with the international standard be adjusted." ${ }^{44}$ As this suggests, though Reisman does not seek to anchor his insights in older writers, there are certainly many parallels with Ehrlich's concerns. It is interesting too to find that Reisman insists that the norms he discusses are kept alive not so much by the sanctioning of breaches (albeit that this can and does take place) but by the decision of the norm- abiders to reaffirm the existence of the norm despite the breach.

If authors such as Reisman emphasise the parallels between legal order and micro- order in society others, such as Jutras think it important to ask " does the normative structure of everyday life mirror the architecture of

\footnotetext{
${ }^{43}$ REISMAN, op.cit. 59.

${ }^{44}$ REISMAN op.cit. 158.
} 
official law ${ }^{45}{ }^{45}$ They urge us to look for differences as well as similarities. It may be instructive for example that the everyday 'feels' non- legal, whilst the law appears self -contained. Tamanaha, too considers it is an error to confuse legal order and social order ${ }^{46}$ It is important, he argues, to see that law is not necessarily a source of social order and social order is not necessarily law- like. ${ }^{47}$ This leads him to be ambivalent about Ehrlich's claims concerning normative order. 'In an important sense, Ehrlich's observations raised a sharp critique of the mirror thesis and the social order function of law .... In another important sense, however, Ehrlich's work is the ultimate extension of the mirror thesis and the social order function of law. In effect his argument is that if positive law does not mirror social norms and does not in fact maintain social order, it has lost its superior entitlement to the claim of being the law, and the label must be given back, or at least shared with the "living law", the actually lived social norms that do satisfy these criteria. ${ }^{48}$ Tamanaha argues that 'The traditionally assumed relationship gets things precisely upside down. It is state law that is dependent on these other sources of social order if it is to

${ }^{45}$ Daniel Jutras, The legal dimensions of everyday life' 16 CANADA JOURNAL OF LAW AND SOCIETY: 45-65. (2001) ${ }^{46}$ BRIAN Z. TAMANAHA, A GENERAL JURISPRUDENCE OF LAW AND SOCIETY, Oxford University Press, Oxford, (2001).

${ }^{47} \mathrm{I}$ am relying on the thorough re-analysis by William Twining, A PostWestphalian Conception of Law, 37 LAW AND SOCIETY REVIEW: 199-258. (2003)

${ }^{48}$ TAMANAHA, 2001 op.cit. at 31. 
have a chance of exerting an influence. ${ }^{49}$ But, of course, this exactly takes us back to what Ehrlich was trying to tell us!

Ehrlich and the normative challenges of plural legalities

How far does this examination of what Ehrlich meant by living law, and what has been made of this idea since, help us make progress with the three issues on which this special issue seeks to focus? A number of points may be made by way of conclusion:

1. There is sometimes a curious sense of deja vue in reading the contributions to this special issue. When Christine Parker tells us in her contribution ${ }^{50}$ that 'the reality of governance means that the aspiration or ambition of law must be to ride the 'frontier' between imperialism (regulation) and being democratic and responsive (emancipation), it is easy to think back to Ehrlich's situation. He too would have recognised 'the new governance image of a network with nodes connecting the strands' in which 'law is not necessarily centered on the state'. He would probably even have agreed that law should 'open out to embrace other regulatory orderings' and that 'it gains its vitality from them, but also seeks to critique them and hold them to standards of justice. Ehrlich's ideas are often more subtle than what has been made of them by later writers, as in the way his

\footnotetext{
${ }^{49}$ TAMANAHA, 2001 op.cit. at 224.

${ }^{50}$ Christine Parker, The Pluralization of Business Regulation (in this issue).
} 
concept of 'living law' was transformed into that of 'law in action' ${ }^{15}$. His starting assumptions about how organisations create normative constraints still offers a valid alternative to, on the one hand, the rational- choice model of individuals seeking to maximise their utilities, and, on the other, a conception of law as a repository of communal meaning and identity ${ }^{52}$. Ehrlich's actors are motivated by a variety of reasons ranging from interest to honour but above all find themselves caught up in institutionalised webs of reciprocity (not always based on fair or equal exchange).

But simply going back to founding scholars cannot provide a quick fix for current dilemmas. Over a range of questions recourse to Ehrlich involves re-interpreting and re-appropriating his arguments for present purposes. ${ }^{53}$ Ehrlich did not, could not, envisage the issues we face today. His arguments have little to do with situations where state norms and organisational norms interact as they do in many late industrial societies. When some of the contributors to this special issue talk of pluralism as a 'social construction' rather than just an objective situation, or when they suggest that legal pluralism should be studied as a strategy used by groups, communities (and even the state itself), they are going beyond Ehrlich's formulations.If anything, re- reading Ehrlich's work can help take us to the

${ }^{51}$ See Nelken,1984 op.cit note 10.

${ }^{52}$ It is an open question whether the individualistic model is as neutral as some contributors to this issue suggest. It could as well be seen as expressing a neo- liberal world view of very particular kind of community. ${ }^{53}$ See Nelken, 2007 op. cit footnote 6 
root of some of the conceptual and practical dilemmas that we have not yet managed to overcome. These include the difficulty of defining law except in terms similar to that of state law, the mistaken tendency to assume that each group or organisation has its own law, the problem of how to distinguish legal from moral obligations, and the conflict between juristic and social- scientific ways of defining law. Likewise, any effort to create or protect multiple legal regimes - including Ehrlich's suggestion that different rule systems could be appropriate for relations between parties 'at peace' as compared to those relevant when they are 'in conflict', faces the risk of 'forum shopping', whereby actors will choose to mobilise those rules most in their interest, irrespective of the larger functional reasons for keeping regimes distinct.

This review has focused more on the descriptive and explanatory value of Ehrlich's concept of living law rather than it's philosophic status or its utility in normative argument. The most important lesson of this paper is that if we want to overcome the 'sense of unconstructiveness, even deadend, in the study of legal pluralism', of which Ido Shahar complains in this special issue, we need to examine non -state legal orders in a larger sociological perspective, rather than get caught up in an argument about definitions. In fact, we still know far too little about when state law or nonstate normative orders are preferred: more attention needs to be given to differences between branches, levels and types of law; in particular, 
different types of legal culture can reflect and encourage very different choices. ${ }^{54}$

Ehrlich's concept was not intended to resolve normative questions such as whether ethnic groups should have a right to their own forms of ordering, but rather to show us why jurists need to take the facticity of such orders into account. He was not discussing whether state law should provide room for non- state law but rather pointing to the many arenas where law not backed up by the state already existed. Nor was he arguing that living law is necessarily better than state law. It would be difficult otherwise to explain the inclusion of anti -state organizations, including criminal organizations, in his definition of living law. ${ }^{55} \mathrm{He}$ also says little about the risk that communities and organisations could repress the individuals subject to their influence, though he does maintain a role for the judiciary (and the legislature) in seeking to bring about social justice as a long- term project. By contrast, some of the recent authors whose attempts to grapple with plural legalities today we have been discussing, do perhaps go too far to the other extreme in risking what Habermas called the ' juridification of

${ }^{54}$ David Nelken Using the concept of legal culture, in 29 AUSTRALIAN JOURNAL OF LEGAL PHILOSOPHY 2004: 1-28.

${ }^{55}$ See now Curtis J. Milhaupt \& Mark D. West, The Dark Side of Private Ordering: An Institutional and Empirical Analysis 67 U. CHI. L. REV. 41 (2000); 
the lifeworld ${ }^{56}$. This is arguably the case for Reisman's proposal to police the world of 'microlaw', or the related suggestion by Melissaris that we need to take as 'seriously' the order of the queue outside a nightclub as we do the ' legal commitment of communities with religious or other moral bonds'.

At the same time, as this suggests, we always need to keep in mind the relationship between empirical and normative enquiries. We have seen that whether we call regimes 'law' or not will depend on our disciplinary affiliations and practical purposes. What makes sense for explanatory purposes will not necessarily map on to normative argument. This may help account for why, paradoxically, John Griffiths sees legal pluralism as at its strongest where it is not acknowledged by the state, ${ }^{57}$ even if, for Simon Roberts ${ }^{58}$ just using the term law is itself a victory for legal centralism. Recognising, as Shahar proposes, that the state is itself a collection of differing regimes may help us get beyond debates about best to overcome 'legal centralism'. The first line of development from Ehrlich's notion of living law that we have discussed, that concerned with 'law beyond the state', offers ample evidence of multiple legalities in the 'law in

${ }^{56}$ JURGEN HABERMAS THE THEORY OF COMMUNICATIVE ACTION, Volume 1 Polity Press Cambridge 1984 and THE THEORY OF COMMUNICATIVE ACTION, Volume 2, Polity Press Cambridge: 1987

${ }^{57}$ See the paper by Shahar in this special issue.

${ }^{58}$ Simon Roberts Against Legal Pluralism op. cit. note 31 
action' of innumerable bureaucracies and functionaries who claim to be acting in the name of the state.

2. A further issue which connects our enquiry with that of this special issue has to do with the relative advantages of looking for overlaps in topics under investigation as opposed to the competing necessity to bring out important differences. In our review of Ehrlich's work we argued that 'Law beyond the state', 'law without the state', and 'order without law' should be seen as overlapping but also distinguishable phenomena, depending on whether we seek to give attention to either the law as it emerges in practice, the existence of rival legal regimes, or the centrality of law as compared to norms in the construction of social order. Ehrlich did not clearly differentiate the power to translate law into action, the way organisations impose roles, and the genesis of 'social facts' by which expectations are enforced without the need of state sanctions. Likewise, he moved promiscuously between the levels of the community, the organisation and the individual. Later writers need to be more precise, and they do not always agree where amongst these factors and levels to search for the origin of normativity (as we have seen, Ellickson and Posner adopt an individualistic approach that is close to that adopted by those who advocate greater privatisation of law $^{59}$ ). Most fundamentally, Ehrlich did not always keep separate the two foundational enquiries of sociology of law: how 'is' become ought and how 'ought' becomes 'is'. Tending to

${ }^{59}$ Like Shamir in this special issue, Ehrlich helps us see how 'private' actors can perform a 'public' role. 
privilege the former problem, he also sometimes gives the impression that facts are enough by themselves to create ' normativity' whereas, as Jonathan Webber has recently reminded us, ${ }^{60}$ normative phenomena ultimately rest on arguments rather than brute facts.

Much the same applies to the matters discussed in this special issue. It is certainly valuable to trace the connections in these literatures which too often ignore each others existence. But it is also important to recognize what they do not have in common. If the idea of living law, which might be expected to exhibit coherence since it was first developed by one author, in fact raises distinct issues, this is even more true for the three themes of privatisation, pluralism and multiculturalism. Because law has so many roles, involving amongst other things, order, regulation and the search for justice, it is unlikely that that we will find a common denominator in thinking about alternatives to state law. From one point of view multiculturalism can indeed be seen as a form of privatisation of law. But in many other respects the two phenomena carry quite different normative implications. As Talia Fisher argues in this special issue ${ }^{61}$, 'the privatization model and multiculturalism represent polar and conflicting conceptions of legal decentralization and that, in the asserted sense, the privatization of law model not only amounts to an anti-state project but also to an anti-communitarian project'.

\footnotetext{
${ }^{60}$ Jeremy Webber, Naturalism and Agency in the Living Law, in Hertogh op. cit . note 1

${ }^{61}$ Talia Fisher, Nomos Without Narrative (in this issue)
} 
The need to give attention to both overlap and differences can be well illustrated from the example of self- regulation by diamond merchants The avoidance of state courts here is over- determined- and illustrates all three themes on which this special issue concentrates. Diamond traders, the large majority of whom belong to very orthodox Jewish communities, do not 'need' to go elsewhere to resolve their disagreements. But going to state courts is also strongly disapproved of. As Talia Fisher explains, the principle of private dispute resolution by diamond merchants therefore represents a different challenge to law than the issue of how far self government should be delegated to orthodox Jewish or other similar culturally distinctive communities: 'The diamond industry regime embodies the privatization model's vision of the mediating social agent to which state lawmaking capacities should be delegated, whereas the network of rabbinical courts in the ultra-orthodox community is a clear manifestation of the multicultural alternative vision of legal decentralization'. In practice, however, these two sources of plural legality reinforce each other. As Barak Richman has shown ${ }^{62}$, numerous constraints make it difficult for members of the orthodox community to abandon their group and this increases their trustworthiness as business

${ }^{62}$ Barak D. Richman 'How community institutions create economic advantage: Jewish diamond merchants in New York', LAW AND SOCIAL INQUIRY 31 - 2 spring 2006: 383-420; see more generally Amitai Aviram A paradox of spontaneous formation: the evolution of private legal systems? 22 YALE LAW AND POLICY REVIEW (Winter 2004) 1 
partners. The intergenerational cooperation between long term dealers in this industry then means that they can enforce contracts that are unenforceable for other merchants. But the economic advantages provided by this groups' avoidance of courts is, however, now under being counterbalanced by increasing use of cheap labour in Asia and by direct selling through the internet.

3. A final consideration concerns the extent to which globalisation and transnational legal processes more generally are changing the relationship between the state and all three of the plural legalities we have been asked to address. Not everyone agrees that globalisation means a decline in reliance of formal law. Lawrence Summers, the American secretary of treasury 'in a world without courts, one lends money to one's brother- inlaw and relies on one's wife's parents to enforce the agreement. In a world without borders, arms length formal contracts become ever more critical to innovation and growth. So too the means of reliably enforcing them. In such circumstances the American preference for rules over understandings and for law over custom, emerges as a major strength' ${ }^{63}$. But, for most observers, we have entered what Santos calls a third period which he describes as 'post-modern legal plurality.' The loss of sovereignty by the nation state (or at least many nation states) in comparison to other agents

\footnotetext{
${ }^{63}$ Lawrence Summers, quoted in Bryant Garth and Austin Sarat 'Introductory essay' in LOOKING BACK AT LAW'S CENTURY, Cornell Univ. Press, Ithaca: 1-31 at p.14. (1999).
} 
or agencies, both reflects and permits the growth of legal pluralism, privatisation of law and multiculturalism. And it changes the terms of what is at stake - we could think for example of the transformation in the role of diasporic cultural minorities when these are linked with large home populations (as in the case of Chinese minorities).

Ehrlich's social context may seem very remote from ours. But, for Teubner $^{64}$, the fact that Ehrlich's ideas were developed in a place in which the state was relatively weak makes them particularly fruitful in helping us understand why global law works differently from international law. As we have seen, the idea of living law has been found particularly relevant to those seeking to understand lex mercatoria and the internet even if exploration of law's role in these phenomena goes beyond those that could have been anticipated by Ehrlich, whether this involves autopoietic theory of communicative sub- systems, or the way the 'architecture' of information technology builds in particular normative choices. But the way we use his work should vary with time and place of its 'appropriation'. In his own time Ehrlich may have been right to underline the limits of the Austrian imperial state ( but even then he probably failed to recognise that the state is not only a source of coercion). It may be debatable how far Ehrlich as a matter of normative choice wanted to limit the role of the state ${ }^{65}$ but his scepticism can be a useful corrective at a time of over-

\footnotetext{
${ }^{64}$ Gunther Teubner, Global Bukowina op cit. note 3.

${ }^{65} \mathrm{Vogl}$ argues that Ehrlich's antagonism to the state has been exaggerated by later commentators. See STEFAN VOGL, SOZIALE
} 
confidence in social engineering. At a time when the state is enfeebled by globalisation, however, associations may if anything have grown too important. We are now invited to find ways to bolster the role of state in controlling the power of pathological corporations that owe responsibility only to their shareholders; ${ }^{66}$ and we worry about the politics of World Bank and the International Monetary Fund as they nudge or whip noncompliant states into line.

Globalisation also changes the form of law. As Ronen Shamir explains in his contribution, 'governance is premised on facilitating 'private' forms of authority: corporations, trade and technical-professional associations, accountancy and credit rating agencies, and standard setting organizations increasingly all assume regulatory roles and intensively experiment with novel forms of legality ${ }^{67}$. Similarly, 'rules and regulations, are partially replaced by a variety of 'guidelines', 'principles', 'codes of conduct' and 'standards' that do not necessarily enjoy the coercive backing of the state.' Christine Parker, for her part, sees these as methods that can also be employed by the responsive state. Reflection on Ehrlich's work is relevant here because of his central focus on the role of associations. It can help us

GESETZGEBUNGSPOLITIK, FREIE RECHTSFINDUNG UND SOZIOLOGISCHE RECHTSWISSENSCHAFT BEI EUGEN EHRLICH (Fundamenta Juridica, Bd. 46), Nomos, Baden Baden (2003). 66 JOEL BAKAN, THE CORPORATION, Free Press, New York (2004). ${ }^{67}$ Ronen Shamir, Socio-finance Governance: A Look at the Equator Principles (in this issue). 
approach the question how far the significance of law made by international bodies, multi- nationals, public and private NGO's, etc is the way this undermines state law or only represents a new vector for its type of legality. Ehrlich wrote mainly about how organisations and associations regulated their own members or business partners rather than how they created a larger order. But what he said about the way they induce conformity in their own membership may also have something to teach us in a world in which the idea or illusion of common participation in an international order is ever more achieved through the signalling and certifying of common standards. ${ }^{68}$ This pressure towards conformity and the 'normalisation' of behaviour and ideas should also be borne in mind in drawing up any balance- sheet of how far we are moving towards or away from plural legalities.

${ }^{68}$ David Nelken, Signaling Conformity: Changing Norms in Japan and China, in 27 MICHIGAN JOURNAL OF INTERNATIONAL LAW 2006: 933-972. 